\title{
Restorative Justice Approach on The Under Age (Minors) Violator of The Traffic Case Accident (Laka) That Lead to Death in Polres Majalengka
}

\author{
Malik AL-Ghazali ${ }^{1}$
}

Abstract. The research is qualitative research in the form of descriptive analysis using sociological juridical approach. Types and sources of data used are primary data and secondary data. Data collected through the study of literature and interviews, while the juridical analysis using qualitative analysis. The approach used for the treatment of children in conflict with the law based on values, principles and norms. Pure approach puts the welfare and wellbeing approach to legal intervention. The punishment model approach to restorative justice called today considered more feasible. For the sake of freedom and rights of the child (fundamental rights and freedom of children) as well as the various interests related to the welfare of children. A limiting factor in the application of Restorative Justice against children in violation of the Act Traffic is due to the factor of legislation often misinterpretation, the factor of law enforcement is the lack of knowledge and skills of investigators in solving criminal cases traffic, factors of infrastructure, a factor of society who do not know information about Restorative justice, Cultural factors personal character actors and victims and their families who do not support the case outside of court settlement or peace. Efforts of traffic guards to avoid conflicts / complaints by victims neutral officer, the offender is directed to the relationship and extend our condolences to the victims, conduct deliberations and request assistance from the Institute of Corrections.

Keywords: Restorative Justice; Traffic Accident; Child Actors.

\section{Introduction}

Traffic accidents are one of the biggest causes of death in Indonesia. The number of victims large enough to provide economic impact (loss of material) social and not least, various preventive measures to repair the traffic by involving various stakeholders results have not been as expected. In improving traffic safety on the road there are three (3) sections that are interconnected by traffic operations, namely: driver, vehicle and road.

With the increased use of motor vehicles, the more problems posed, such as breaking traffic signs or driving a vehicle exceeds the maximum allowed speed limit, driving a motor vehicle without a driver's license and children under the age of driving a motor vehicle. As a way of solving these problems required the regulations governing road traffic and road transport.

Traffic regulations are currently in place in Indonesia is Act No. 22 of 2009 on Traffic and Transportation. The enactment of Act No. 22 of 2009 on Traffic and

\footnotetext{
1 Student of Master of Law, Universitas Islam Sultan Agung Semarang and POLRI email: malikalghazalipolri2018@gmail.com
} 
Transportation, is expected to mematuhiaturan society, to the creation of safety, security, and the smoothness of traffic and to improve the welfare of the community. An accident is an omission, which negligence is also a criminal offense is certainly no criminal liability. What if the accident committed by a child that causes other people died. when a lot of consideration if the child had to be convicted, so that the necessary efforts are undertaken to provide guidance and protection of children, both with regard to the institutional and legal instruments more adequate as Act No. 4 of 1979 on Child Welfare, Act No.11 of 20122012 About Child Criminal Justice System and Act No. 35 of 2014 on the Amendment of Act 23 of 2002 on Child Protection.

One solution that can be taken in handling the criminal case the child is restorative justice approach, which is implemented by way of diversion. Restorative justice is a process of settlement is done outside the criminal justice system by involving the victim, the perpetrator, the victim's family and the perpetrator's family, the community and the parties concerned with a crime that happened to reach an agreement and settlement.

Restorative justice is considered a way of thinking / new paradigm of looking at a crime committed by one. Restorative justice is a process of diversion in which all parties involved in a specific criminal acts together to solve problems, create an obligation to make things better by involving Child Victims of the Son, and the community in seeking solutions to repair, reconciliation, and reassuring that is not based on retaliation. But basically, Act No. 11 of 2012 on the Criminal Justice System This child is set for the overall settlement process Children who deal with the law began the investigation stage to the stage after undergoing criminal coaching. ${ }^{2}$

Through the police discretionary authority to determine the form of diversion to a criminal act of children. Discretion is the authority possessed by police for stop investigation by freeing a suspect case of children, or do diversion in order for the child to avoid legal proceedings more. Diversion can be regarded as an unconditional transfer of pediatric cases (suspected of committing a crime) of the formal process. ${ }^{3}$

Diversion program is best effort for children, especially for offenses less serious. This would involve law enforcement officials to tell the child that what he had done wrong and reminded him not to repeat it again.

The government has set about a child as a criminal in Act No. 11 of 2012 on the Criminal Justice System Child states that, in the case of Children yangBerkonflik with the law are children who have aged twelve (12) years, but not yet the age of 18 (eighteen ) years who allegedly committed crimes. The principles adopted in the Criminal Justice System Children in whom is the child's best interests, respect for the views of the child, survival and child development, coaching and mentoring of children, deprivation of liberty and criminal prosecution as a last resort, and the avoidance of retaliation. In Article 3 of Act No. 11 of 2012 on the Criminal Justice System Child states that every child in criminal proceedings has the right of them:

- Treated humanely and in accordance to the needs of with the age;

\footnotetext{
${ }^{2}$ Santi Kusumaningrum Penggunaan Diversi untuk Anak yang Berhadapan dengan Hukum. http://www.idlo.int/bandaacehawareness.htm Accessed on 2 June 2018

3 lbid.
} 
- Separated from adults;

- Recreational activities;

- Freedom from torture, punishment or other cruel, inhuman, and degrading and dignity;

- Not sentenced to death or life imprisonment and

- Not arrested, detained, or imprisoned, except as a last resort and in the shortest period of time.

Juvenile justice system shall prioritize restorative justice approach, and must be pursued versioned with the aim to keep the child from the stigma of evil, to achieve peace between the victim and children, resolve cases of children outside the judicial process, prevent children from deprivation of liberty, encouraging people to participate, and embed sense of responsibility to children.

Legal approach in the case of children in conflict with the law covers children are considered to have not understood the wrong that has been done, so it is appropriate that given a reduced sentence, as well as differing punishment for children and adults who commit criminal acts. Assuming that the child can not do evil or doli incapax and can not fully responsible for his actions, when compared with adults, children are believed to be more easily formed and resuscitated. ${ }^{4}$

The position of the child in criminal law as legal subjects is determined from the shape and system of the society and children as a group are poor, or underage. In respect of the protection of children, the state and the government is responsible to provide facilities and accessibility for children to ensure optimal growth and development and direction. In Indonesia, there are several legal instruments governing child as a criminal as in Act No. 11 of 2012 on Juvenile Justice System and Act No. 3 of 2002 on Child Welfare.

The approach used for the treatment of children in conflict with the law based on values, principles and norms. Pure approach puts the welfare and well-being approach to legal intervention. The punishment model approach to restorative or restorative justice called today considered more feasible. For the sake of freedom and rights of the child (fundamental rights and freedom of children) as well as the various interests related to the welfare of children. Indonesian state guarantees a basic principle of law enforcement against children, which is based on the best interests of the child, gives the right to life, survival and development, and respect for the views of the child.

Data traffic accidents involving children under the age of 16 years shows that in 2017, specialized in the area of Majalengka police station, children under the age of being violators of traffic jumped dramatically. Data from unit Laka Police Majalengka show in 2016 there are only 40 cases, but in the year 2017 to 80 cases or surged 100 percent, while for the data in the month of May 2018 there were 25 cases involving children under the age of the offender traffic violations and five of these cases is a case of causing death of Laka.

Implementation of diversion in Indonesia as mandated in Act No. 11 of 2012, is still constrained by the law enforcement officers who do not understand the application of Diversion for Children in Conflict with the Law to achieve Restorative Justice.

\footnotetext{
${ }^{4}$ http://hizbut-tahrir.or.id/2013/10/12/batas-tanggungjawab-pidana-anak/ accessed on 2 June 208.
} 
Based on the background described, the authors are interested in making research on Restorative Justice Approach On The Under Age (Minors) Violator Of The Traffic Case Accident (Laka) That Lead To Death In Polres Majalengka.

Based on the background of the problems described problems can be formulated as follows: How does the application of Restorative Justice in the settlement Laka causing death to the minors perpetrator in Polres Majalengka? How obstacle in the settlement Laka which causes death in the minors perpetrator with the principles of Restorative Justice in Polres Majalengka? How is solution to overcome the obstacles that arise on the settlement Laka which causes death in underage offenders with the principles of Restorative Justice in Polres Majalengka?

\section{Research Methods}

This type of research used in this study is a qualitative research. Qualitative research is a study aimed at describing and analyzing phenomena, events, social activities, attitudes, beliefs and thoughts of people individually or in groups. Some descriptions are used to discover the principles and explanations which leads to the conclusion.

The research approach used in this study is juridical Sociological, where the study was conducted by reviewing the issues examined in terms of legal science in the reviewing legislation and to see and associate with the reality that is in its implementation which aims to describe the activities or events activities or natural events in daily practice in the community.

\section{Results and Discussion}

\subsection{Application of Restorative Justice in the settlement Laka causing death by the minors perpetrator in Polres Majalengka}

Restorative Justice in the science of criminal law should aim to restore the state as before the crime. When there are people who have violated the law then the situation will be changed. Then that is where the role of the law to protect the rights of the victims of crime. In the conventional criminal justice process known their restitution or compensation to the victim, while the restoration has a broader meaning. Restoration includes the restoration of the relationship between the victim and the perpetrator. Recovery of this relationship can be based on a mutual agreement between the victim and the perpetrator. The victim can pass on the losses suffered and the offender was given a chance for redemption, through the mechanism of compensation, peace, social work, and other agreements. ${ }^{5}$

Implementation of restorative justice in Majalengka Police until now done through Diversi that is expected to resolve the case laka then with children as perpetrators. The purpose of Restorative Justice through Diversion process is to avoid children from detention so that children as perpetrators avoid the label / stamp of children as criminals and teach children to be responsible for his actions. Results to be achieved by

\footnotetext{
${ }^{5}$ Angkasa Saryono Hanadi dan Muhammad Budi Setyadi. Model Peradilan Restoratif dalam Sistem Peradilan Anak (Kajian tentang Praktik Mediasi Pelaku dan Korban dalam Proses Peradilan Anak di Wilayah Hukum Balai Pemasyarakatan Purwokerto) . 2012 p. 8
} 
the restorative jastice is to encourage children to take responsibility for his actions give children an opportunity to replace the wrong done to do good with the victim.

Steps taken sat then in the handling of lacquer then the perpetrator of children in conflict with the law $(A B H)$ where investigators are required to mediate between the two parties involved are already receiving reports of victims, and published reports of Police (LP) then created Warrant Investigation and investigators apply restorative justice by seeking diversion system, investigators sent a letter Into Correctional Centers (Bapas) with the aim of assisting the child Actors and do research community and assisting during the investigation. Investigators sent a letter to the Legal Counsel for the offender mentoring children during the investigation. Diversion system to be implemented was attended by the party that is part of the victim was accompanied by his family and the village, while the suspect was present, accompanied by family and village as well as the Hall of Corrections and Legal Counsel. When SDH diversion agreement is reached then the victim has agreed that the matter be resolved amicably and do not demand into legal channels. Furthermore, the investigator sends letter Diversion agreement and minutes of diversion agreement with the District Court will next get a ruling from the District Court that ordered the investigators to discontinue the investigation. If an agreement is reached diversion investigators only send letters of agreement diversion and News event is to get the decision / determination Diversion of the District Court. However, if no agreement is reached Diversion means the victims are still demanding and investigators continue the case in accordance with Law in force. If no agreement is reached versioned Investigators send SPDP (Notice of Commencement of Investigation) to the Attorney General. Further Processed appropriate juvenile justice Act No. 11 of 2012. Investigators are not required to make an arrest if there is a guarantor.

\subsection{Obstacles in the settlement Laka which causes death by the minors perpetrator with the principles of Restorative Justice in Polres Majalengka}

Restorative justice movement began as an effort to rethink the unmet needs in the judicial process. Restorative justice widening the circle of stakeholders or the parties involved in the events or cases in which not just the government and the perpetrator but also included victims and community members. ${ }^{6}$ Restorative Justice is a popular alternative in various parts of the world for the treatment of children in conflict with the law as it offers a comprehensive and effective solution. Restorative Justice aimed at empowering victims, perpetrators, families and communities to improve a tort, using awareness and conviction as a basis to improve social life. The main problems the application of restorative justice lies in the follow factors, namely factor own law, law enforcement factors that the parties establish and apply the law, the factors supporting infrastructure of law enforcement, community factors which are valid or applicable law. ${ }^{7}$

\footnotetext{
${ }^{6}$ Howard Zehr \& Ali Gohar The Little Book of Restorative Justice (Pennyslvania: Good Books 2003) p. 17

${ }^{7}$ Makarao 2013. Penerapan Restorative Justice Dalam Penyelesaian Tindak Pidana Yang Dilakukan Oleh AnakAnak. Guru Besar IImu Hukum Universitas Islam As-syafi'iyah Jakarta p. 47-48
} 
Restorative justice as one of the search for peaceful conflict resolution outside of the court is still difficult to apply. In Indonesia, many customary laws could be restorative justice, but its existence is not recognized by the state or not codified in national law. Customary law could resolve the conflicts that arise in society and giving satisfaction to the parties in conflict. The emergence of the idea of restorative justice as a critique of the application of the criminal justice system with a restraint that is considered not effectively resolve social conflicts. The reason, the parties involved in the conflict are not involved in conflict resolution. Victims still being bullied, imprisoned also raises new problems for the family and so on. ${ }^{8}$ Investigators constraints faced in the implementation of restorative justice in Rembang is less cooperative the perpetrator against the victim after the accident scene on the other hand does not want to forgive the perpetrator Victims causing conflict. In addressing the incidence of children as perpetrators of traffic accidents by doing justice investigators restoration process required to mediate the two sides both perpetrators and victims, but their third party muddy the consolidation and the lack of public understanding of the diversion approach is still lacking.

\subsection{Solutions to overcome obstacles that arise on the settlement Laka which causes death by the minors perpetrator with the principles of Restorative Justice in Polres Majalengka}

Prominent characteristics of restorative justice that is where the crime was placed as a symptom of social action and not just a violation of criminal law. Crime is seen as an action that harms others and damaging social relationships. Unlike the criminal law as a crime that has attracted the country's problems. Only the state can give punishment, despite the fact that indigenous communities could provide punishment. The implementation must promote justice, which is confirmed by the terms of integrated justice, that justice for perpetrators, justice for the victims and justice for the people. Effort from Sat So to suppress digits accident Children in Police Majalengka such as provide socialization on understanding the safety of traffic and the minimum limit of age to drive in schools with the goal of minors, disseminating targeted parents with courses Police at twilight, gatherings in villages with the aim of understanding to parents about the importance of orderly traffic, and forbid children to drive a vehicle before the age of 17 years and do Active Enforcement Violations potentially laka then targeted minors. Efforts of traffic guards to avoid conflicts / complaints by victims neutral officer, the offender is directed to the relationship and extend our condolences to the victims.

\section{Closing}

\subsection{Conclution}

Majalengka district police completed the crime scene of traffic accidents to children as perpetrators through the diversion process in order to avoid children from detention

\footnotetext{
${ }^{8}$ Setyo Utomo 2014. Sistem Pemidanaan Dalam Hukum Pidana Yang Berbasis Restorative Justice Mimbar Justitia Fakultas Hukum Universitas Suryakancana Cianjur Vol. V No. 01 p. 86.
} 
where children will get the label / stamp child as a criminal, mentally rescue children from the impact of detention, and that children are able to be responsible with their actions. Diversion done to divert the criminal proceedings out of formal process for settling disputes amicably done.

Investigators constraints faced in the implementation of restorative justice is less cooperative the perpetrator against the victim after the accident scene, the victim does not want to forgive their perpetrators and the third parties that disturb the atmosphere as well as the lack of understanding about the diversion in the community. Results to be achieved by the restorative jastice is to encourage children to take responsibility for his actions give children an opportunity to replace the wrong done to do good with the victim.

The efforts of the Traffic Unit officers to avoid conflicts / complaints by victims neutral officer, the offender is directed to the relationship and extend our condolences to the victims, conduct deliberations and request assistance from the Institute of Corrections.

\subsection{Suggestions}

The practice of restorative justice is not only implemented in the investigation phase alone, but also in the stage of prosecution and trial stage, so we need new regulation that authorizes the prosecutor and judge the child perform restorative justice in the juvenile justice system in the future.

In the implementation of restorative justice needs to be a format of the follow-up steps after the mediation, so that the victim remains protected and served their interests. The practice of mediation not only do the offenses of theft, embezzlement and destruction of goods, but extended to other offenses committed by children. Mediation implementation needs to be openness between the perpetrator, victim and law enforcement, so that the parties really get the benefit of this mediation. Education is necessary for law enforcement about the mediation and implementation.

\section{Bibliography}

[1] Andi Hamzah 2008 Asas-Asas Hukum Pidana Edisi Revisi : Rineka Cipta Jakarta

[2] Angkasa Saryono Hanadi dan Muhammad Budi Setyadi. Model Peradilan Restoratif dalam Sistem Peradilan Anak (Kajian tentang Praktik Mediasi Pelaku dan Korban dalam Proses Peradilan Anak di Wilayah Hukum Balai Pemasyarakatan Purwokerto) 2012.

[3] Howard Zehr \& Ali Gohar The Little Book of Restorative Justice (Pennyslvania: Good Books 2003.

[4] Makarao Penerapan Restorative Justice Dalam Penyelesaian Tindak Pidana Yang Dilakukan Oleh Anak-Anak Guru Besar IImu Hukum Universitas Islam Assyafi' iyah Jakarta 2013.

[5] R.Wiyono 2016 Sistem Peradilan Pidana Anak Di Indonesia Sinar Grafika,Jakarta

[6] Santi Kusumaningrum Penggunaan Diversi untuk Anak yang Berhadapan dengan Hukum http://www.idlo.int/bandaacehawareness.htm. 
[7] Setyo Utomo Sistem Pemidanaan Dalam Hukum Pidana Yang Berbasis Restorative Justice Mimbar Justitia Fakultas Hukum Universitas Suryakancana Cianjur Vol. V No. 012014.

[8] Act No. 4 of 1979 About the Welfare of Children

[9] Act No. 11 of 2012 on Child Criminal Justice System.

[10] Act No. 14 of 1992 on Traffic and Transportation

[11] Act No. 22 of 2009 regarding Traffic and Road Transportation

[12] http://hizbut-tahrir.or.id/2013/10/12/batas-tanggungjawab-pidana-anak/ 